\title{
NEWS
}

Items for publication in the News are welcomed and should be sent to:

R.F. Guy

National Library of Scotland

312-320 Lawnmarket

Edinburgh EH1 2PJ

Scotland

UK

\section{General news}

\section{FID Education and Training Committee}

The FID Council at its meeting in September 1988, approved the appointment of Professor Nick Moore, Head of the Department of Librarianship and Information Studies, City of Birmingham Polytechnic, as Chairman of the FID Education and Training Committee. On January 1, 1989, with the beginning of Professor Moore's term of office, the FID/ET Secretariat will be transferred from Syracuse University, USA, to the City of Birmingham Polytechnic, UK.

\section{Beta Beta Delta}

Beta Beta Delta is the European Regional Chapter of the Pittsburgh-based Beta Phi Mu International Library Science Honor Society. Beta Phi Mu was founded in 1948 at the University of Illinois as a fraternity for library school graduates. Today it has more than 20,000 members in more than 40 'chapters' at American library schools. Its purposes are to recognize high scholarship in the study of librarianship and to support professional and scholarly projects.

The European chapter, Beta Beta Delta, was formed by Professor Paul Kaegbein at the University of Cologne. In 1988, Margarete Payer, Fachhochschule für Bibliothekswesen (College of Librarianship), Stuttgart, West Germany, was elected chairperson.

The purposes of the society are defined in $\S 2$ of its constitution: 'Beta Beta Delta Chapter is devoted to the promotion and the support of librarianship and library science. This will be achieved by:

- funding of research projects,

- publication of scholarly contributions in the fields of librarianship, information science, library education and training,

- organisation and conduct of seminars, workshops, conferences and related activities.' 
Beta Beta Delta particularly aims to realize these goals by recruiting members from all European countries. In this way the cooperation between librarians, and the role of librarianship as a profession will be enhanced. Personal contacts are important among Beta Phi Mu's large number of members in the United States. Therefore, a Beta Beta Delta member travelling to America will certainly find contact in almost every larger library.

At present, the European chapter has members in Austria, Finland, West Germany, Turkey and the United Kingdom. According to the regulations of Beta Phi $\mathrm{Mu}$, membership is offered to:

- teachers at library schools, and

- graduate librarians holding a first class or upper-second class honours degree, or a higher degree in library and information studies.

Contact for membership:

Mrs Margarete Payer

Fachhochschule für Bibliothekswesen

Wolframstrasse 32

D-7000 Stuttgart 1

West Germany

Information Science in Kenya

The first class of 49 students began studying with the faculty of Information Sciences at Moi University, Eldoret, Kenya in November, 1988. The first degree being offered is the BSc.

\section{Awards}

\section{Glasgow Online}

Strathclyde University's Department of Information Science was among the prize winners in the 1988 Aslib/ISI Award for Innovative Information Management. Patricia Baird and Noreen MacMorrow were awarded second prize (£250) for the development of the hypertext system, 'Glasgow Online.' The winner was Tome Associates for their 'Tome-Searcher' software package and the other runners-up were Dun \& Bradstreet for their 'Profile Plus' financial data interpretation and analysis system.

According to the panel of judges, 'Glasgow Online' is a simple-to-operate interactive database of graphics and texts which exploits the power of Apple's HyperCard to provide a wide range of information on Glasgow.

Further details can be obtained from:

Professor Blaise Cronin, Head of Department

Department of Information Science

University of Strathclyde

Livingstone Tower

26 Richmond Street

Glasgow G1 1XH

UK 
ALISE Awards

At the 1989 Annual Conference of the Association for Library and Information Science Education, held in Washington, DC, the following awards were made.

\section{ALISE Scholar and Research Awards}

The 1989 Research Grant Award was given to Leigh Estabrook, Dean of the School of Library and Information Science at the University of Illinois. The grant will fund a one-year project concerning 'New Technologies and Library Work.'

Three doctoral dissertations were recognized as being superior studies in the library and information science field. Those receiving awards and making presentations were:

Eugenia Brum of the University of Illinois; 'Exploratory study of chief information officers in Fortune service and industrial organization.'

Elizabeth Liddy of Syracuse University; 'The discourse-level structure of natural language texts.'

Lawrence Mondschein of Rutgers University; ' $R \& D$ productivity: relationship to selective dissemination of information in the corporate environment.'

For more information concerning competition for research and scholar awards from ALISE for 1990, contact:

Marion Paris, Research Committee

Graduate School of Library Services

University of Alabama

PO Box 870252

Tuscaloosa, AL 35487

USA

The deadline for proposals and manuscripts is October 1, 1989. For more information on ALISE, contact:

Daniel Callison

Publication Officer for ALISE

School of Library and Information Science

Indiana University

Bloomington, IN 47405

USA

\section{ALISE Service Award}

The ALISE Service Award was presented to F. William Summers, Professor and Dean of the School of Library and Information Studies at Florida State University. His previous service as President (1980) and board member of ALISE (1980-84) helped to enhance the stature of ALISE through his efforts to represent quality library education to legislators, other associations, and to his colleagues in education.

Contribution to Library and Information Science Education

The ALISE Award for Professional Contribution to Library and Information 
Science Education was presented to Robert M. Hayes, Dean and Professor of the School of Library and Information Science at UCLA.

Hayes has been appointed to positions of major importance to library and information science education by such bodies as the American Library Association, the Department of Education and the Council on Library Resources. Hayes twice chaired ALA's Committee on Accreditation, and he chaired the steering committee for the US Department of Education project on accreditation.

For information concerning nominations for the 1990 ALISE Award for professional contribution, contact:

Desretta McAllister-Harper

Awards and Honors Committee

School of Library and Information Science

North Carolina Central University

Durham, NC 27707

USA

\section{Courses}

\section{Thailand}

Chulalongkorn University announces a new degree programme leading to a Certificate of Advanced Study in Library and Information Science. The programme will offer instruction in a wide range of topics in library and information science, with specializations in library management, library automation and information science. Students must complete an approved programme of at least 30 credit hours and must be actively involved in research and professional development. For more information, contact:

Department of Library Science

Chulalongkorn University

Bangkok

Thailand

Venezuela

The Universidad Simón Bolívar is offering a graduate programme in management of information services. Students are required to take a minimum of 32 credits and to present a final thesis on a specific problem and its solution within the field of information services. English proficiency is also required. The total cost of tuition for the 32 credits is US $\$ 1,000$ for non-Venezuelans. For more information, contact:

Coordinador del Postgrado en Estudios de la Información

Universidad Simón Bolívar

Apartado 89,000

Caracas 1081A

Venezuela 


\section{Research}

Newcastle upon Tyne Polytechnic, UK

The Department of Librarianship and Information Studies tendered a successful bid to the European Commission in January 1988 for support for liaison with several mainland European library schools, under the Commission's ERASMUS scheme. These visits are to take place in the current academic year and will, it is planned, explore possibilities for staff and student exchange under the scheme. A further bid is being prepared to build on this in the 1989/90 academic year. The Department has in turn been approached by a European institution, with which negotiations are now proceeding.

Further details from:

Department of Librarianship and Information Studies

Lipman Building

Newcastle upon Tyne NE1 8ST

UK

\section{Optical products}

A project surveying the use of optical information products in all types of libraries and information centres in Western Europe is being undertaken by FID (Fédération Internationale d'Information et de Documentation). The survey will cover the Nordic countries and countries within the European Economic Community. The survey is to obtain both quantitative and qualitative data on the use of CD-ROM and other optical information products.

The study is based on a survey undertaken in the United States by Dr Ching-chih Chen, where the methodology for the survey was developed. The questionnaire that has been developed for this project is also being used in the United States, so that comparative data will be available from the project. The data analysis procedures have been established in the United States and will be used for data analysis and reduction. The study is intended to provide definitive data on the use and potential use of new optical information products in Western Europe, and is planned as part of a comprehensive survey to allow comparison with data already collected for the United States and data to be obtained for other parts of the world.

In addition to providing benchmark and comparative data on the use of optical information products, it is expected that the study will also provide information on the degree of market penetration of optical information products, definitive information on the types of user, products used and levels of use, information on user expectations, and indications for future developments in optical products. The final report which will be published as a result of the project will focus on the state of the art of the use of optical information products in the mentioned region, and will compare data with data collected for the United States. 
The project is being funded partly by the Commission of the European Communities, Directorate General XIII-Telecommunications, Information Industries and Innovation; by Nordinfo; and by FID. The project is supported by the International Federation of Library Associations and Institutions (IFLA).

The study is being conducted by two highly respected professionals and experts in the field of applications of new information technology-Dr Ching-chih Chen (Associate Dean and Professor at Simmons College, Boston, USA) and Dr David Raitt (Editor, The Electronic Library, The Netherlands). The data in the Nordic countries are being collected through Nordinfo at the Technical Research Centre of Finland (VTT) by Anelli Heimbürger.

The questionnaire will be sent out to approximately 10,000 libraries and information centres in the above mentioned region, and will start at the beginning of February 1989. A second phase of the project is being planned to collect data for other parts of the world, especially the developing countries.

Further details can be obtained from:

Fédération Internationale d'Information et de Documentation (FID)

Postbus 90402

2509 LK Den Haag

The Netherlands

Tel: +3170140671

Fax: +3170834827

Telex: $34402 \mathrm{~KB}$ GV

\section{Sheffield University, UK}

Interpersonal skills training in the private sector and in a range of public agencies are being studied to provide information that will further the effective development of interpersonal skills training in library and information organizations, and improve the performance of staff. Information is being gathered by interviewing trainers and observing training programmes; and by identifying, collecting, reviewing and evaluating methods and materials used in interpersonal skills training.

The project will run from October 1988 to June 1989, and is being funded by the British Library Research and Development Department.

For more details, contact:

Bob Usherwood

Sheffield University Department of Information Studies

Western Bank

Sheffield S10 2TN

UK

Tel: + 44742768555 ext. 6181 


\section{Software}

\section{Training for Library Microcomputer Systems}

A new textbook-diskette package provides library educators with a classroom tool for introducing automated library systems to either students of library science or library staff members. Understanding Library Microcomputer Systems, a 128-page textbook written by Roger C. Palmer, discusses the planning and implementation of micro-based library systems. The accompanying diskette contains a complete acquisitions system that is currently used by several special libraries. With this program, students are able to gain actual experience with an automated library system and can enter catalog data, search the online database and generate reports. The acquisitions system operates on an IBM PC or compatible equipped with 512K RAM, DOS 2.1 or higher, and two 360K floppy disk drives. The textbook-diskette package is available for $\$ 29.95$ plus $\$ 15.00$ postage outside the USA. To order, write to:

Pacific Information Inc.

11684 Ventura Boulevard, Suite 295

Studio City, CA 91604

USA

Micro CDS / ISIS

Under contract with Unesco, FID has agreed to undertake a feasibility study and a system analysis on the introduction of generalized relational database features in the mini-micro version of the CDS/ISIS software package, Version 2, with a view to accommodating, in a manner compatible with the Common Communication Format (CCF) linking techniques, a number of library and information functions-such as acquisition and circulation applications and integrated databases of interrelated projects, institutions, persons and bibliographic records. The project is being undertaken on behalf of FID by the Computer/Automation Institute of the Hungarian Academy of Sciences.

Mini-micro CDS/ISIS has been derived from the mainframe CDS/ISIS software. The CDS/ISIS (Computerized Documentation System/Integrated Set of Information System) is a table-driven, generalized Database Management System designed specifically, but not exclusively, for handling textual databases of any size. The software is particularly suitable for bibliographic information systems, allowing the user to define a database made up of separate elements, to enter new data into the database, to correct existing data, to retrieve the data using the inverted file technique, to display the data, and to sort and print the data following the user's own specifications. Mini-Micro CDS/ISIS was designed at Unesco for use on IBM or IBM-compatible microcomputers. Mini-Micro CDS/ISIS runs on the MS DOS 2.0 operating system or any of the higher versions. Version 1 of the system is available free of charge to not-for-profit institutions in Unesco member countries. A 
regular column on the developments and news on CDS/ISIS is published in the UNISIST Newsletter published by Unesco, General Information Programme.

Further information on CDS/ISIS is available from:

Mr Giampaolo Delbigio

Division of Software Development and Applications (IPS/SDA)

Unesco

7 place de Fontenoy

75700 Paris

France

Dialog

Dialog OnDisc Discovery Training Toolkit, designed for teaching and practising online searching, is available at a price of $\$ 250$.

Further details from:

Dialog Information Services

3460 Hillview Avenue

Palo Alto, CA 94304

USA

\section{Publications}

\section{Education and training for technology transfer}

Education and training for technology transfer, edited by Marta L. Dosa and Thomas J. Froehlich. The Hague, FID, 1988 (FID Publication 670). xiii, 218 pp. DFl 60. ISBN 92-66-00670-X.

Education and training for technology transfer was the theme of the seminar organized by the FID/ET Education and Training Committee chaired by Marta Dosa (USA), that was held preceding the 43rd FID Congress in Montreal, Canada, from September 8-11, 1986. The seminar brought together more than 50 participants, many of them from developing countries. Speakers were from Canada, Costa Rica, Czechoslovakia, Denmark, Egypt, Finland, India, Israel, Mexico, Nigeria, Thailand, USA and Zambia.

The main theme, technology transfer, was broadly interpreted to include the transmission of research findings to entrepreneurs, practitioners and policy makers to support their work, especially the solving of specific new problems (national activities), and the dissemination or trade of technology, data and methods from one country to another (international activities).

Sessions covered technology transfer as a field of study; for national development; international issues and national perspectives; education and training for information systems and services to industry; preparing information specialists for research; education programmes; and international organizations and resources. The FID Education and Training Committee, with a membership representing 41 
countries, aims to identify problems at both regional and international levels, to suggest solutions and to stimulate action, to effect communication and liaison between experts, and to stimulate exchange of experience.

Orders can be sent to:

FID General Secretariat

Postbus 90402

2509 LK Den Haag

The Netherlands

LIBS

The British Library Research and Development Department and the Library and Information Technology Centre have launched a new information service called 'LIBs' (Library and Information Briefings). Published eight times during the year with an annual bound updated volume, LIBs will cover the legal and policy environment of information and new technologies such as CD-ROM, desktop publishing, value added networks and standards such as OSI.

Contact:

Ms Roslyn Cotton

British Library R\&D

2 Sheraton $\mathrm{St}$

London W1V 4BH

UK

Tel: +4413237049

\section{Conferences}

ALISE

The theme for the 1990 Annual Conference of the Association for Library and Information Science Education to be held in Chicago, January 3-5, 1990 is 'Education for Information Work: a Dialog among Information Disciplines.'

Robert Grover, Dean of the School of Library and Information Science at the University of South Florida, will serve as the Chair of the Conference Planning Committee. Miles Jackson, Dean of the School of Library and Information Studies at the University of Hawaii, will serve as President for the association this year. Jackson has outlined the following programme for the conference.

'The educational preparation of information professionals is increasingly being discussed by professional organizations other than the Association for Library and Information Science Education. As examples, the Association for Computing Machinery, Association of Records Managers and Administrators, Institute of Electrical and Electronics Engineers, American Assembly of Collegiate Schools of Business, American Institute of Decision Sciences, American Association of School Librarians, and Association for Educational Communications and Technology are 
concerned with curricula matters related to aspects of education for information work. These professional organizations represent three types of programmes for the education of information professionals:

(1) those dedicated to teaching for routine, highly structured data processing tasks (payroll, inventory);

(2) those that prepare personnel to serve less rigid systems designed for problem solving, simulation or decision-making processes, mainly characterized by programmes in MIS, typically required in business and industry; and

(3) those serving more flexible, yet complex and encompassing information systems for collecting, storing, retrieving and disseminating less dedicated information such as that collected by libraries.

'A goal of the 1990 ALISE Conference will be to identify the theoretical and philosophical foundations of information science as viewed by other information professionals and other disciplines. In addition, presentations at the conference will attempt to identify convergence or parallels in the information professions with implications for professional education.'

For more information, contact

Daniel Callison

Public Relations Officer for ALISE

School of Library and Information Science

Indiana University

Bloomington, IN 47405

USA

\section{Information Specialists for Europe}

The purpose of the conference, which is organized under the auspices of Fachbereich Bibliothekswesen, Information, Dokumentation, Fachhochschule Hannover, and will be held from October 17-19, 1989, at the Congress-Centrum Hannover, FRG, is to provide a forum for exchanging and evaluating new developments and recent innovations related to the role of information specialists in the European Community. Representatives of different educational organizations in the field of librarianship, archiving, information and documentation within the countries of the EEC and bordering countries will gather with delegates from industry to discuss educational requirements for information specialists in the next decade. Further key issues are the contents of and synchronization between the different training courses.

An exhibition of related materials, relevant services and educational institutions will take place in parallel. Conference languages are German and English (no simultaneous translation will be provided).

For further information and pre-registration please contact:

Fachhochschule Hannover

Fachbereich BID

Hanomagstrasse 8

D-3000 Hannover 91

FRG 


\section{Polar Libraries Colloquy}

The 13th Polar Libraries Colloquy (formerly Northern Libraries Colloquy) will be held in Rovaniemi, Finland, June 10-14, 1990. Sessions will be held at the Rovaniemi City Hall and at the University of Lapland. The object of the conference is to promote information exchange among polar libraries or information services and research institutes.

Participants will be librarians, documentalists, information specialists, and scientists or researchers, who will all be able to take part in an exchange of experience with colleagues from other countries. Such an exchange is essential to further development of 'Man's future in Arctic Areas.'

\section{Theme}

The theme of the 13th Polar Libraries Colloquy will be 'Man's Future in Arctic Areas.' This theme will be illustrated by:

- invited lecturers;

- presentations, chosen from among abstracts submitted;

- exhibitions and demonstrations; and

- visits and tours.

\section{Proposed sessions}

The future and central problems in the Arctic-environment, technology and culture.

The problems of arctic communication and procurement of knowledge.

New areas in arctic research.

The research and research institutes of the Arctic-the problems of the small research units.

Collection of the Polar literature on CD-ROM files.

Organization of the science and information policies in the arctic countries.

\section{Call for papers}

The Organizing Committee of the 13th Polar Libraries Colloquy is pleased to invite everyone who would like to contribute to the Colloquy to submit an abstract $\left(\frac{1}{2}-1\right.$ page) by not later than October 31, 1989.

Submit the title of your paper with abstract to:

Arctic Centre

University of Lapland

PO Box 122

96101 Rovaniemi

Finland

Tel: +35860324275

Fax: + 35860324270

Telex: 19205519 